\title{
開口部を有するアトリウム空間に対応した 温熱環境予測モデルの開発 \\ DEVELOPMENT OF A SIMPLIFIED PREDICTION MODEL FOR INDOOR THERMAL ENVIRONMENTS IN ATRIUMS WITH OPENINGS
}

\author{
諏 訪 好 英*, 藤 井修二**, 湯 浅 和 博*** \\ Yoshihide SUWA, Shuji FUJII and Kazuhiro YUASA
}

\begin{abstract}
A simplified prediction model was developed to predict indoor thermal environments in atriums with openings. Characteristics of cross ventilation through openings were studied using CFD technique based on the standard $k-\varepsilon$ model. According to the simulation results under several conditions, modeling strategies were obtained to predict draft airflow volume, inlet airflow angle and the airflow state in atriums.

Finally, a simplified prediction model was developed as a computer softwere to calculate indoor thermal environments in atriums with openings. Predicted results on temperature distribution using this software showed a good agreement with CFD results, and it was verified that developed model provides acculate predictions on indoor thermal environments.
\end{abstract}

Keywords : atrium, openings, indoor thermal environments, natural ventilation, simplified prediction model

アトリウム, 開口，屋内温熱環境，自然換気，簡易予測モデル

\section{1. 緒言}

都市におけるアメニティ空間として, ラウンジやエント ランスホールにアトリウムを有する建築物が近年さかんに 建設されるようになった。アトリウム空間では，空調制御 された屋内環境の中で屋外環境と同様の開放感を享受でき るなどの利点を有する反面, ガラス面の割合が大きいこと, 天井高の大きな大空間となることなどに起因して空調制御 が難しくなる傾向がある1)。特に天井高の大きなアトリウ ムでは温度成層の発達により垂直方向の温度分布に大きな ばらつきを生じる傾问があり，屋内居住域での温熱快適性 や空調目荷の予測には垂直温度分布を考慮した温熱環境設 計手法が必要となる。これまでアトリウム内の空調制御法 や現象予測手法に関して各種の研究が行われており，垂直 温度分布を考慮した屋内温熱環境設計手法としていわゆ る゙マクロモデルを用いた熱負荷計算手法が開発されてきた 2) 7)。

ところで実際のアトリウムでは，熱だまりの除去などを 目的として半開放式構造や開閉式の開口部を設けた構造が しばしば採用される。しかし従来のモデルではいずれもア
トリウム内部をある程度独立した閉鎖空間として扱ってお り，外部風や煙突効果により駆動される通風・換気効果を 考虑することは困難であった[注1]。また内部容積の大きな アトリウム空間では，自然通風などを利用した外気の導入 により屋内の換気・空調に必要な消費エネルギーを大幅に 削減できる可能性もあり, 省エネルギー設計の観点からも 自然通風を考虑したアトリウム内温熱特性の検討が重要と 考えられる。

開口部を有するアトリウムでは開口を介して外気の流入 や屋内空気の流出を生じるが，その主な駆動源のひとつが 外部風に起因するものと考えられる。本研究では流体の数 值解析手法を用いてアトリウム内外の気流解析を実施し, 各種風向，風速条件および開口設定条件についての数値解 析結果から，開口部における通風特性の考察を行った。ま た考察の結果得られた諸特性をマク口的な予測モデルの形 にまとめ，開口による自然通風の影響を考慮したアトリウ ム内温熱環境予測モデルを構築した。本報では数值解析に よる自然通風特性の検討結果と, 構築した温熱環境予測モ デルの概要について報告する。
* 㧣大林組技術研究所 数值解析研究室

** 東京工業大学大学院情報理工学研究科 教授・工博

*** 東京工業大学建築学科 助手・工博
Computational Eng. Dept., Technical Research Inst., Obayashi Corp. Prof., Graduate School of Information and Sci. and Eng., Tokyo Inst. of Technology, Dr. Eng.

Research Assoc., Dept. of Arch. and Building Eng., Faculty of Eng., Tokyo Inst. of Technology, Dr. Eng. 


\section{2. 数值解析による自然通風特性の考察}

\section{1 数值解析手法および対象モデル}

外部気流により駆動される自然通風の特性を把握する ため, 開口部を含めたアトリウム内外の気流状態を数值解 析した。計算にはSIMPLE 法8)による3 次元定常解析手 法を適用し, 運動量方程式の移流項の離散化には 3 次精度

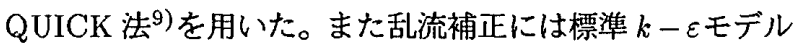
10）を用いた。なおここでは基本的な通風特性の考察を目 的としているため，自然対流のような熱的要因による成分 は考虑していない。数值解析に用いた手法および境界条件 の概要を表 1 にまとめて示す。

対象とした建築物は図 1 に示すような $20 m(L) \times$ $20 m(W) \times 40 m(H)$ の矩形断面を有する中空構造とし, 想 定した境界層流中に単体で存在するものと仮定した。対象建 築物を含好解析領域全体の大きさは $80 \mathrm{~m}(L) \times 80 \mathrm{~m}(\mathrm{~W}) \times$ $80 \mathrm{~m}(H)$ である。基本モデルでは風上側壁面の中央 6 简所 に $1.5 \mathrm{~m} \times 1.5 \mathrm{~m}$ の開口を，また風下側壁面に $11 \mathrm{~m} \times 38 \mathrm{~m}$ の開口を設け,これらの開口部を介して連結されるアトリ ウム周辺気流と屋内気流とを同時に数值解析した。

\section{2 自然通風による外気流入量の考察}

先述したように開口部での自然通風量は外部気流の状態 により大きく変化するため，本来は想定した条件ごとに屋 内外の気流状態を解析する必要があると考えられる。しか し本研究で指向するような簡易予剆手法では，外部気流状 態に関する膨大なデータを各時刻について扱うことは困難 である。ここでは風圧係数を用いた簡易的な通風量予測手 法についてその適用の可能性を検討した。建築物外表面 での風圧係数は，対象建築物高さにおける流入境界での風 速を基準として次式により定義した。すなわち，

$$
C=\frac{2 g}{\gamma} \frac{P_{w}}{v_{0}^{2}}
$$

図 1 に示した基本モデルについて屋内外気流の数值解析 を行い，その外表面における風圧係数の分布を算出した。 開口を設けた場合, 開口なしの場合について解析した垂直 断面内の気流分布を図 2 に，また図 2 のそれぞれの場合お よび開口なしの条件で風速を変化させた場合について集計 した風上側壁面での風圧俰数の垂直分布を図 3 に示す。壁 面に開口を設けるとその近傍での風圧係数は局部的に変化 するが，全体的な分布状態は開口なしの場合の傾向を保持 している。風圧係数の值そのものについては開口の設定条 件とある程度独立に考えてよいものと判断できる。また今 回想定した範囲では，風速を変化させても風压係数の值は ほとんど変化しないことがわかった。これらのことから， 基準となる開口条件，風速条件についてあらかじめ数值解 析した風圧係数を参照することとすれば，任意の条件につ いての通風量予測が可能と考えられる。ただし風圧係数の 分布は風向により大きく変化するから，参照用の風任係数 のデー夕は風向条件ごとに用意しておく必要がある。 本研究では開口なしの条件について求めた風圧保数を用
表 1 䕬值解析手法の概要

\begin{tabular}{|c|c|}
\hline 勘碳方程式 & $\begin{array}{l}\text { Navier-Stokes 方程式 } \\
\text { 熱伝行方程式** }\end{array}$ \\
\hline 浮力モデル゙ & Boussinesq近似 \\
\hline 话流モデル & 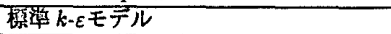 \\
\hline 竐頶落子 & 直交格子系, スタッガート留数配瞢 \\
\hline 䔟流項の就儌化 & 3 次精度 QUICK 法 \\
\hline $\begin{array}{l}\text { 压力䈬正 } \\
\text { アルコリスム }\end{array}$ & $\begin{array}{l}\text { SIMPLE 法 } \\
\text { (収束到定值 }=10^{-3} \text { ) }\end{array}$ \\
\hline 境界条件 & 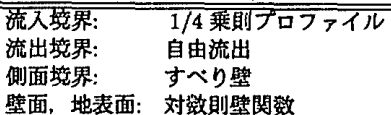 \\
\hline
\end{tabular}

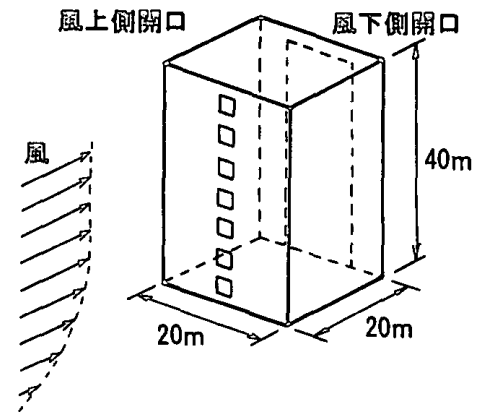

图 1 対象建筑物のそデル

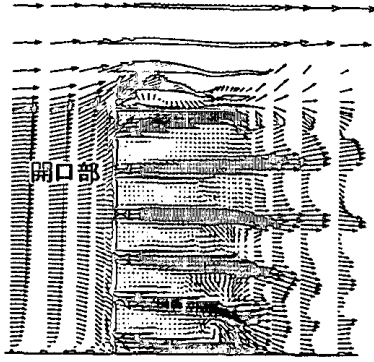

a) 网口を股けた场合

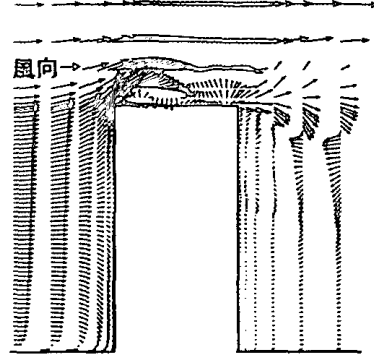

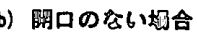

图 2 対象建筑物周辺気流の繁值解析結果

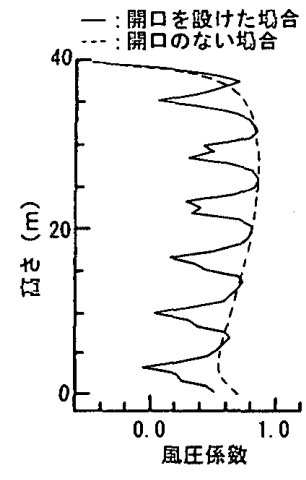

a) 開口の有無による迹い

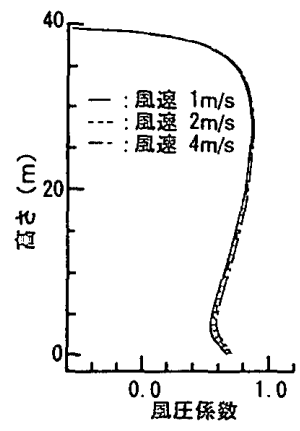

b）国速が舆なる场合
図 3 風上側壁面での風圧係数の分布

いて通風量予測を行うこととした。それぞれの開口部での 通風量は，流入側，流出側通風量の総和が等しくなること を利用して次式から求められる。

$$
\sum_{i=1}^{N} Q_{0_{i}}=\frac{2 g}{\gamma} \sum_{i=1}^{N} \alpha_{i} A_{i} \Delta P_{i}=0
$$




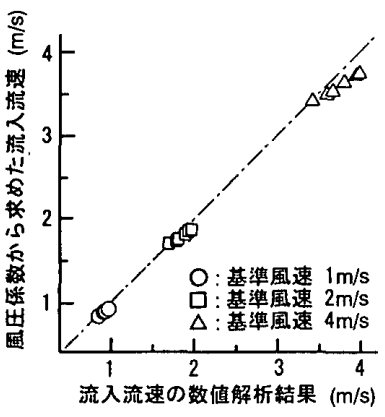

a）基隼風速が異なる埸合

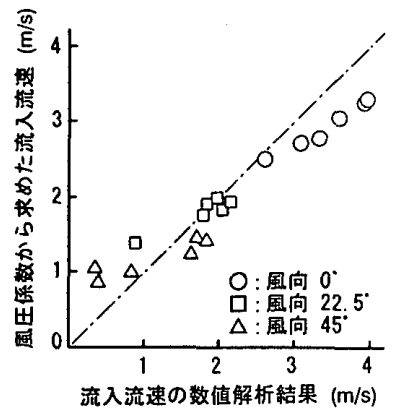

b）風向が翼なる場合

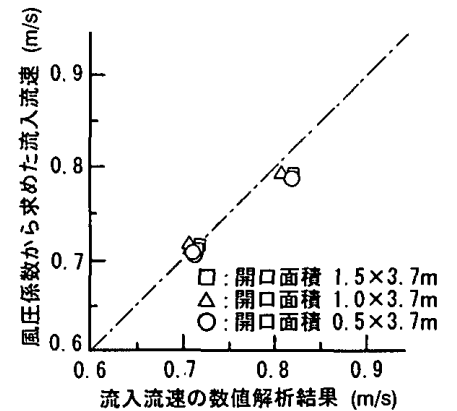

c）開口面樌が異なる場合

図 4 通風量予測計算と数值解析との比較

各種の風向，風速条件および開口条件について，(2) 式 による予測手法でどの程度現象を再現できるかを確認する ため, 開口を設けたモデルにより別途実施した数值解析の 結果と比較した。各種風速条件, 開口条件についての通風 量予測結果の比較を図 4 に示す。ここで，数值解析による 通風量予測結果は開口部分での速度成分から直接換算した 值を示している。いずれの条件においても，(2) 式により 算出した予測値は数値解析により求めた通風量とよく一致 しており，(2) 式のような簡易的な方法でも開口からの外 気流入量を十分評価できることが確認された。

\section{3 開口からの外気流入角度に関する考察}

図 2 に示した気流解析結果からは，開口の設置位置の高 さによって外気の流入角度が異なることがわかる。図 5 は 建築物高さの異なる場合, 風下側開口条件が買なる場合に ついて比較した外気流入角度の垂直方向の分布である。開 口からの外気の流入角度は開口位置の絶対値に依存するも のではなく，建築物高さに対する開口設置位置の高さの比 によって決まるものと考えられる。この仮定にしたがって 整理した図 5.a) では，建築物高さ $40 \mathrm{~m}$ の場合と $20 \mathrm{~m}$ の場 合の流入角度の分布はよく一致している。また図 5.b) の 結果からは，風上側開口部における流入角度が風下側の開 口条件に依存しないことがわかった。図 2 の結果からもわ かるように, 開口から流入した気流は強い慣性力を有して おり，屋内においては後流側の影響を受けずほぼ直進する 傾向がある[注2]。

建築物高さに対する開口設置位置の高さの比 $r_{H}$ と風上 㑡流入角度 $\theta_{i n}$ との関倸を 2 次曲線と仮定して最小 2 乗近 似した結果, 次式が得られた。

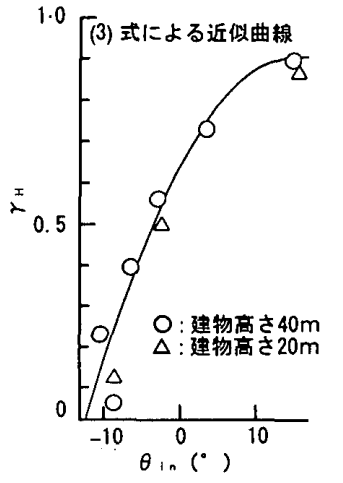

a）建築物高さが異なる堨合

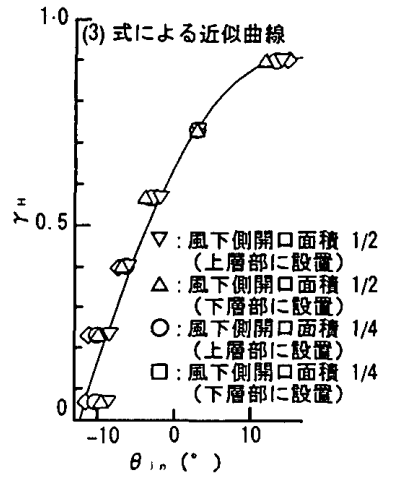

b）風下側開口条件が異なる堨合
図 5 開口位置と流入気流の角度との関係

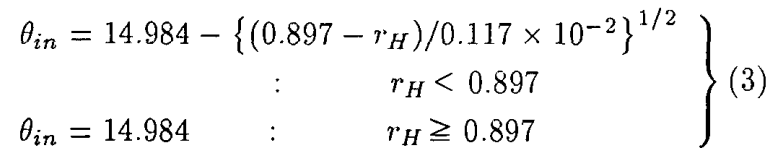

\section{4 屋内流入後の気流状態に関する考察}

2.3 節でも考察したように，開口から流入した気流は屋 内でも強い慣性力を有しており，噴流的な気流状態を形成 している。容積の大きなアトリウムでは開口部の面積が相 対的に小さく，開口部からの通風気流は噴流吹き出し口に おける絞り効果と同様の作用を受けるものと考えられる。

(3) 式から $\theta_{i n} \simeq 0^{\circ}$ と予測される $r_{H}=0.65$ の位置に 開口を 1 所のみ設けて前節までと同様の解析を行い, 屋 内へ流入した後の気流状驡を考察した。ここでは開口近傍 での計算格子をさらに細分割したモデルを用いた。解析結 果を図 6 に，また噴流理論から求まる軸対称噴流の径方向

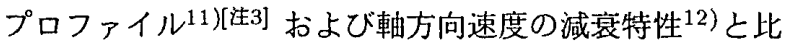

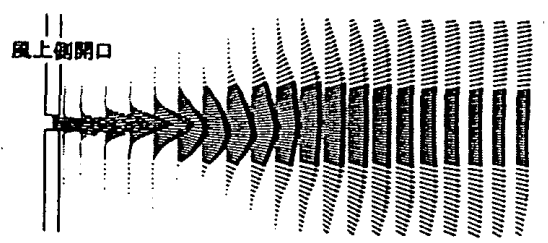

図 6 流入気流の数値解析結果

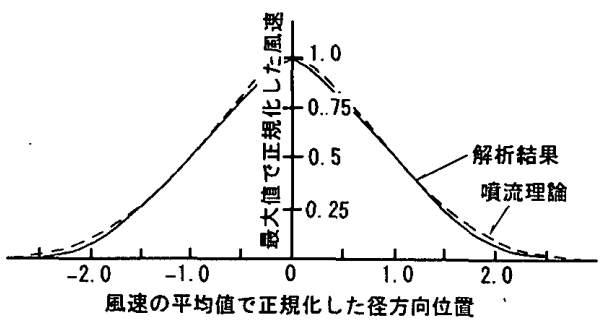

日) 軸方向速度の径方向プロファイル

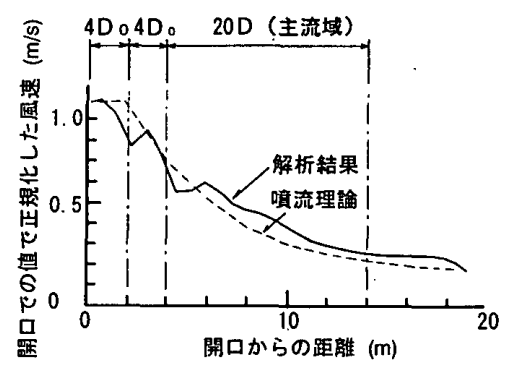

b）軸方向速度の減衰特性

図 7 流入気流の状態と噴流理論との比较 
較した結果を図 7 に示す。解析結果はいずれの理論とも よく一致しており，開口から流入した流れにより形成され る屋内気流分布は噴流として近似できるものと判断した。 なお，噴流理論を用いて評価した流入気流のスロー定数は $K_{p}=5.08$ であり, 長方形吹き出しロについての文献値 $\left(K_{p}=5.0\right)$ とほぼ一致した。

\section{3. 外気の影響を含めたマクロモデルの構築}

アトリウム内では温度成層が発達しやすく，屋内の温度 は垂直方向に分布を持つが，水平方向には大きな温度差を 持たない場合が多い。いわ㠴るクロモデルを用いた温熱 解析ではこの性質を利用し, 垂直方向に分割した屋内各層 での流量収支，熱量収支から層間での熱移動を計算する。

本研究ではマクロモデルに流入外気の影響を加え, 開口 部を有するアトリウムを対象ししたマクロ的な屋内温熱環 境予测モデルを構筑した。本章では開発した予測モデルの 概要を示す。なおマクロモデルを用いた屋内温熱環境の計 算方法としては宮川2),3)，戸河里ら4),5)，石田ら6)，7)の方 法がすでに報告されており，基本的にはこれらのモデルを 参考として予測モデルの開発を行った。本研究では開口部 からの流入外気の扱いに力点を置いているので，ここでは 全体的なアルゴリズムの基本的な考え方と開口からの流入 気流の扱いについてのみ詳述する。

\section{1 層間熱移動之流宣収支}

アトリウムの内部空間を図 8 に示すような層に分割し, 層間の流量収支，熱量収支を考える。各層の 4 方向の壁面 には，壁表面温度と壁面流評価のための 2 次元領域を想定 している。

各層の熱量収支を考えると，j層についての熱平衡式は 次のように表される。

$$
\begin{aligned}
M_{j} & \frac{d T_{j}}{d t}=\sum_{\substack{i=1 \\
j+1}}^{N b} \sum_{n=1}^{N k} r_{i j n} A w_{n} \alpha c_{n}\left(T s_{i}-T_{i}\right) \\
& +\sum_{i=j-1, i \neq j}^{j+1} C p r Q r_{j i}\left(T_{i}-T_{j}\right) \\
& +\sum_{i=j-1, i \neq j}^{j+1} C b_{j i} A_{f}\left(T_{i}-T_{j}\right)+H_{j}+H_{J E T}^{A C}+H_{J E T}^{N}
\end{aligned}
$$

$$
\begin{aligned}
H_{J E T}^{A C} & =\sum_{k=1}^{j} C p r Q_{J O U T_{k}}^{A C}\left(T_{k}-T_{j}\right) \\
& +C p r Q_{J E T}^{A C}\left(T_{J E T}^{A C}-T_{j}\right) \\
H_{J E T}^{N} & =\sum_{k=1}^{j} \operatorname{Cpr} Q_{J O U T_{k}}^{N}\left(T_{k}-T_{j}\right)+C p r Q_{0}\left(T_{0}-T_{j}\right)
\end{aligned}
$$

ここで右辺は第 1 項から順に,

・壁面流による熱移動,

・層間の空気移動に伴う熱移動,

・乱流拡散による層間熱移動,

- 内部発熱,

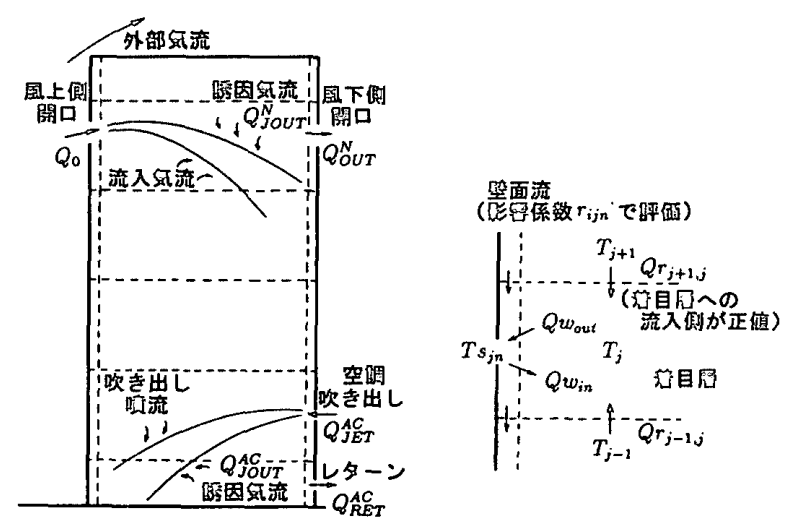

图 8 流入気流を考慮したマクロモデルの榴念图

・空調噴流により与えられる熱量,

・開口からの外気流入により与えられる熱量 を表す。また各層における流量収支は次式で計算できる。

$$
\begin{gathered}
\sum_{k=1}^{N k}\left(Q w_{i n_{j k}}-Q w_{o u t_{j k}}\right)+\sum_{i=j-1, i \neq j}^{j+1} Q r_{j i}+Q_{J E T}^{A C}+Q_{0} \\
-\left(Q_{J O U T}^{A C}+Q_{J O U T}^{N}+Q_{R E T}^{A C}+Q_{O U T}^{N}\right)=0
\end{gathered}
$$

ここで壁面流，空調吹き出し噴流などの扱いには戸河里 $ら^{4), 5)}$ ，石田ら ${ }^{6), 7)}$ と同様の方法を採用した。屋内各部で の空気移動と熱移動とを同時に計算する戸河里ら，石田ら のマクロモデルでは，層間熱移動に関して配分係数など経 験的な定数の設定を必要としない。この考え方により算出 した熱量配分保数が実験的に求めた配分係数とよく一致す ることはすでに石田ら吕が論じている。一方 2 章での検討 結果からは, 開口からの流入気流は噴流として近似できる ものと考えられる。噴流モデルなどの適用により外気流入 に伴う屋内各部の空気移動量を評洒するこよができれば， 外気寄与率のような経験定数を用いることなく現象を再現 できると考えた。

なお，本予測モデルの計算に必要な経験定数として乱 流搪散に関する $C b$ 值があるが，これを固定値としても 十分な精度で現象予測できることが従来の研究におい て示されている。ここでは戸河里ら吕)の計算例に従い, $C b=2.0 \mathrm{kcal} / \mathrm{hm}^{2{ }^{\circ} \mathrm{C}}$ 採用した。ただし冬季には下層温 度が上層温度よりも高くなる逆転現象を生じ，層間での熱 移動量が非常に大きくなる場合がある14)。このような場 合については一時的に $C b \simeq \infty$ として上下層の温度を均一 化させることとした。

\section{2 外気流入特性のモデル化}

2 章での考察結果と 3.1 節に示した基本的な考えにしたが い，風上側開口只ら自然通風により流入する外気の特性を モデル化した。以下その内容を示す。

[外気流入豆および外気流入角度の算出法]

開口部での外気流入量の算出には (2) 式を用いることと した。流入風量を決定するための風圧係数は，あらかじめ 風向ごとに数值解析した結果から開口設置位置にあわせ線 形補間して求めることとし，これらの值をテーブルとして 


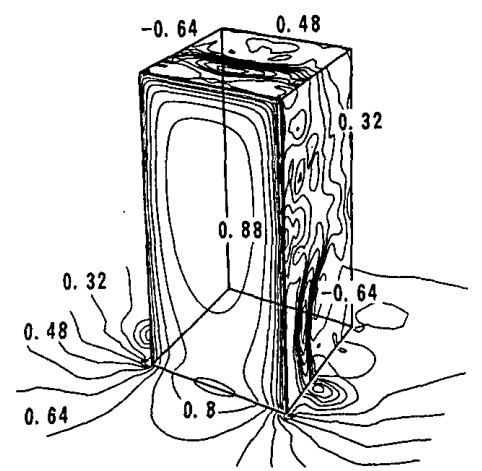

図 9 バッファに保管した参照用風圧係数の分布

参照用バッファに保管した。アトリウムの水平断面形状が 正方形であると仮定すると，風向が異なる場合の風圧分布 は風向角 $90^{\circ}$ ごとに回転対象となる。また風向角 $0 \sim 90^{\circ}$ の間では $45^{\circ}$ を境に鏡面対象の分布状態が現れるため，結 局参照用バッファには風向角 $0 \sim 45^{\circ}$ の間で風向角ごとの デー夕を用意すればよいこととなる。本研究で用いた気象 データの風向分解能は $22.5^{\circ}$ であるので, 参照用バッファ には風向角 $0^{\circ}, 22.5^{\circ}, 45^{\circ}$ の場合について求めた 3 種類 の風圧分布を保管することとした。各壁面での風圧係数の デー夕集計には 2 次元等間隔格子(格子間隔 $1 m \times 1 m$ ) を 用い，数值解析結果から各格子中央点での風圧係数を換算 してバッファ內の 2 次元配列に割り当てた。参照用データ として集計した風圧係数の分布を図 9 に示す。

なお各開口部での流入，流出判定には対象時刻における 風向デー夕を用い，外気流入角度の決定には (3) 式を用い ることとした。

\section{[屋内での外気流れ之熱移動量の扱い]}

屋内流入後の外気の流れは非等温噴流モデルにより近似 した。周囲温度との差による浮力効果を考慮すると，噴流 中心軸の軌跡は次式で与えられる。

$$
\begin{aligned}
y= & x \tan \theta_{i n}+A r\left(\frac{x}{D_{0} \cos \theta_{i n}}\right)^{2} \\
& \times D_{0}\left\{0.51 C_{s}\left(\frac{x}{D_{0} \cos \theta_{i n}}\right)+0.11\right\} \\
A r= & g D_{0} \frac{T_{0}-T_{a}}{Q_{0}^{2}\left(273.16+T_{a}\right)}
\end{aligned}
$$

なお式中の $\theta_{i n}, K_{p}$ 式中では $C s$ として間接的に用いられ ている)には，2 章で得られた結果を利用する。

開口から流入した気流を噴流として扱うと，その中心軸 上における風速および温度は (8) 式から次のように求めら れる。

$$
V_{s}=\frac{V_{0} \cdot K_{p} \cdot D_{0}}{s \cdot p}, \quad T_{s}=T_{a}+0.83\left(T_{0}-T_{a}\right) p^{2} \frac{V_{s}}{V_{0}}
$$

ここでは噴流速度が $0.25 \mathrm{~m} / \mathrm{s}$ 以下となった時点，または 噴流軌跡が壁面に到達した時点でその到達層を決定するこ ととし, 流入気流の有する熱量は直接到達層へ輸送される ものとして熱移動量を計算した。なお噴流の軌跡は以下の
各式で与えられる。

$$
s_{n}=\sum_{i=1}^{n} \sqrt{\Delta x^{2}+\Delta y_{i}^{2}}, \quad p_{n}=\left\{1+\left(\frac{\Delta y_{n}}{\Delta x}\right)^{2}\right\}^{-1 / 4}
$$

噴流軌跡の計算には $\Delta x$ ごとに周辺温度と噴流温度とを比 較しながら順次 $\Delta y$ を求めて行く方法を採用した。

なお，外気流入に伴う到達層以外での熱移動は誘引に よって引き起こされる。噴流軌跡が層間を横切る時点での 風量は炊式で与えられる。

$$
Q_{J_{i}}=0.9 \times\left\{\pi \frac{V_{s}}{2\left(K_{p} / s\right)^{2}}\right\}_{r \rightarrow \infty}
$$

噴流が $i-1$ 層から $i$ 層へ流入するものとすると， $i$ 層にお ける誘引風量が次のように求まる。

$$
Q_{J O U T_{i}}=Q_{J_{i}}-Q_{J_{i-1}}
$$

\section{2 壁表面温度の算出}

壁面流や輻射熱伝達の評価に必要な壁表面温度は，屋内 外空気との対流熱伝達，透過日射による受熱，壁体内部で の熱伝導および各内壁間での相互輻射による熱交換などの 熱平衡から求められる。壁表面温度に関しても (4) 式と同 様の熱平衡式が以下のように表せる。

$$
\begin{array}{r}
\left.\lambda \frac{\partial T s_{n}}{\partial x}\right|_{x=s}=\alpha c_{n}\left(T_{j}-T s_{n}\right) \\
+\sum_{k=1}^{N w} \alpha r_{k n} \Phi_{k n} T s_{k}+R s_{n}
\end{array}
$$

（6）式の各項は順に以下の要团による熱移動を表す。

・壁体内部の熱伝導,

・壁表面での対流熱伝達,

・壁間の相互輻射,

・日射，照明などによる長波長成分の吸・放熱 同様の熱平衡式を裹面についても立て，内壁表面温度につ いて整理すると，壁表面温度に関する連立方程式が以下の ように得られる。

$$
\begin{gathered}
T s_{n}-E s_{n} \sum_{i=1}^{N w} \Phi_{i n} T s_{i}=E x_{n}+E_{0} T_{j} \\
E s_{n}=\left(1-\frac{K g}{\alpha i}\right) \frac{\alpha r}{\alpha i} \\
E x_{n}=\frac{K g}{\alpha i}+\left(1-\frac{K g}{\alpha i}\right) \frac{R s}{\alpha i}, \\
E_{0}=\frac{\alpha c}{\alpha i}\left(1-\frac{K g}{\alpha i}\right)
\end{gathered}
$$

(11) 式の各項については後述する検証計算に必要となる事 象のみを考慮した。壁体内での熱伝導 (熱買流) や相互輻 射などの熱移動要因についてはこれまで多くの研究が行わ れており，さまざまなモデルが提案されている。本研究で 
開発した予測モデルではそれぞれの要因による取得熱量の 計算と (11) 式による表面温度の計算とが独立した形となっ ているため, 各要因に関するモデルの追加, 修正は比較的 容易に行える。ただしガラス面の割合が大きなアトリウム では，日昼の取得熱量として透過日射が支配的となる。ま た壁表面での対流熱伝達については壁面近傍での気流状態 や空気側温度との差により熱伝達率が大きく変化する。こ こでは，開発した予測モデルで採用した透過日射亡対流熱 伝達率の扱いについて示しておく。

[透過日射の扱い]

屋内へ入射する透過熱量は透過面での日射の入射角度 により異なる。このため内壁の各部で受照する透過日射熱 量は，その透過光がどのガラス面から入射したかによって 違ってくる。簡単のため天井面およびすべての透過側壁面 がガラスの場合を想定すると，受照面での各透過面からの 受照面積比は次のようにして算出できる。

図 10.a) は天井面からの透過光が床面に投影する場合を 示している。いま床面と同レベルの無限平面を仮定すると， 天井の角点 $a 1\left(x_{a 1}, y_{a 1}, z_{a 1}\right)$ の投影点 $a 3\left(x_{a 3}, y_{a 3}, z_{a 3}\right)$ は 次式で与えられる。

$$
\begin{gathered}
x_{a 3}=\left(z_{a 1}-z_{a 3}\right) \times \cos |A| / \tan h \\
y_{a 3}=p \times\left(z_{a 1}-z_{a 3}\right) \times \sin |A| / \tan h+y_{a 1} \\
p=1 \quad: \quad\left(-90^{\circ}<A \leqq 0^{\circ}\right) \\
p=-1:\left(0^{\circ}<A \leqq 90^{\circ}\right)
\end{gathered}
$$

図では $a 1$ の投影点 $a 3$ が床面 $\square_{(a 2, b 2, c 2, d 2)}$ の内部に存在す るが，投影点の位置は幾何学的な関係から以下の 3 通りの パターンをとる。すなわち,

・投影点が床面に存在する場合

・投影点が床面に存在しない場合 (アトリウムの外側に ある場合)

・投影点が床面を構成する各刀上にある場合

投影点が床面に存在する場合，床面で受照する日射は壁 面 $\square_{(d 1, d 2, a 2, a 1)}, \square_{(a 1, a 2, b 2, b 1)}$ おおよひ天井面 $\square_{(a 1, b 1, c 1, d 1)}$ を透過した日射の 3 種類であり，その面積比は

$$
\square_{(a 2, a 3, f, d 2)}: \square_{(a 2, b 2, e, a 3)}: \square_{(a 3, e, c 2, f)}
$$

となる。一方，投影点が床面の外部または各辺上に位置す る場合には 1 または 2 筒所の透過面から入射していること となる。壁面での受照についても同様の関係から図 10.b) のような受照状熊が予測できる。ただし壁面の場合，各層 のレベルごとに受照面積比を計算する必要がある。図の例 では第 4 層のみが 3 種類の透過光を，他の層では 2 種類の 透過光を受照しており，それぞれの層壁面において受照面 積比が定義できる。本研究ではそれぞれのパターンについ て場合分けを行い, 各透過面, 受照面での入射角を考慮し て各面での透過面皘比から受熱量の算出を行った。

\section{[壁表面での熱伝達率]}

外壁表面屋内外壁表面での空気との熱伝達率はそれぞれ 以下の式で評価した。

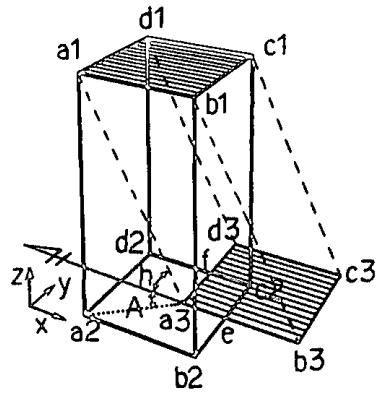

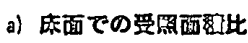

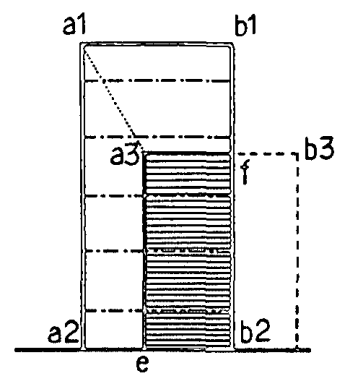

b) 面での受照面整比
图 10 䢪過日射の受照面積比の算出方法

内壁表面:

$$
\left.\begin{array}{ll}
\alpha c=0.138 \Delta T^{0.25} & : \text { 水平下向き } \\
\alpha c=2.18 \Delta T^{0.31} & : \text { 水平上向き } \\
\alpha c=1.78 \Delta T^{0.32} & : \text { 垂直 }
\end{array}\right\}
$$

外壁表面:

$$
\left.\begin{array}{ll}
\alpha c=5.3+3.6 v_{w} & : v_{w} \leqq 5.0 \\
\alpha c=6.47 v_{w}^{0.78} & : v_{w}>5.0
\end{array}\right\}
$$

ここでは建筑物外表面の熱伝達率に関して風圧係数と同様 のテーブルを作成し，あらかじめ屋外気流解析の結果から 算出した熱伝達率の分布を参照用バッファに保管した。

3.3 マクロモテルの計算アルゴリズム

3.1,3.2 節に示した計算モデルを組み合わせ，温熱環境 解析ソフトウエアの形にまとめた。計算のアルゴリズムを 図 11 に示す。層間熱移動および壁表面温度の計算式 ((4) および(12) 式)について後退差分法を適用すると，各方程 式は行列式の形となる。ここに開口からの外気流入や日射 による壁面の受熱, 空調や内部発熱による熱量供給の影響 などはすへて係数行列の要素中に考虑されることとなる。 このため計算アルゴリズムの主要部分は, 係数行列の作成, 行列式の計算および温度，流量フラックスなど物理量の算 出といった操作から構成されている。

なお層間熱移動と流量収支, 内壁表面温度とは熱伝達や 屋内気流状態などの変化を介して密接かつ相互に関連し合 う。すなわち各層の温度が变われば噴流軌跡が変化し，そ の結果，外気や空調気流の到達層が変化する。また層間熱 移動と内壁表面温度との関係についても壁面流と対流熱伝 達率の変化により同様の相互作用が生じる。ここでは層間 熱移動と流量収支, 内壁表面温度の計算を連成させ，各時 刻での状態予測に 10 回程度の収束計算を行うこととした。

\section{4. マクロモデによる試計算と検証}

\section{1 予測モテルと牧值解析との比較}

試作した温熱環境解析ソフトウエアを用いて開口部を有 するアトリウムについての温熱特性予測を行い，同じ条件 について実施した数值解析結果と比較した。数値解析の手 法は 2 章に示したものと同様であるか，屋内外各部の温度 差による浮力効果を考虑するため熱対流連成解析を行って いる。 


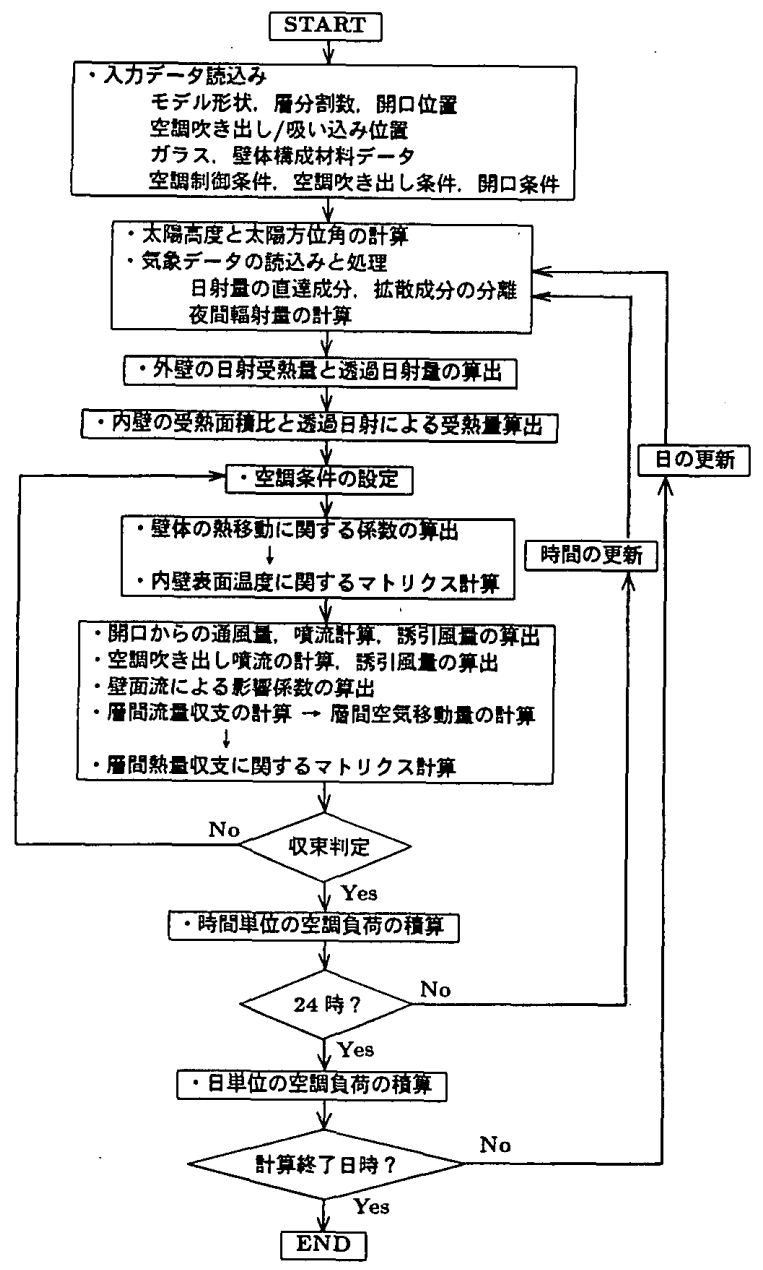

図11＼cjkstart試作したソフトゥエアの計算アルゴリズム

計算対象としたアトリウムの天井面，壁面はすべてガラ スで構成されているものとした。想定したアトリウムの構 造を図 12 に，その構造概要を表 2 にそれぞれ示す。ここで は第 5 層の東西壁面に各々 5 ヶ所ずつの開口を設けた場合 を想定し，図 13 に示すような気象条件について屋内温熱 環境の予測を行った。図に示した風速条件は地上 $30 \mathrm{~m}$ で の観測値であるが，ここでは屋外気流の垂直方向プロファ イルが $1 / 4$ 乗則にしたがうものと仮定し, 開口設置高さで の気流速度を算出して計算に用いた。なおアトリウムの建 設場所は東京 (北緯 $35.68^{\circ}$ ，東経 $139.77^{\circ}$ ) を想定した。

夏季 (8月) および冬季 (2月) 晴天日について実施した本 モデルによる予測結果と数值解析結果を図 14 に示す。夏 季には成層的な温度分布が形成されること，冬季には上昇 流, 下降流による熱移動量が大きく，屋内温度が均一化さ れることなど，本予測モデルによる結果は数値解析の結果 上よく一致している。空調気流や開口からの流入気流が壁 面まで到達する部分では，これらの気流と壁面流とが干渉 する。このため壁面近傍での気流状態には，雨者の間に若 干の違いも認められた。ただし垂直温度分布は定量的に一 致しており, 全体的な流量収支, 熱量収支については本予 测モデルで十分な精度で現象を再現できるもの上判断でき る。なお冬季条件についての数值解析結果では第 4 第 5

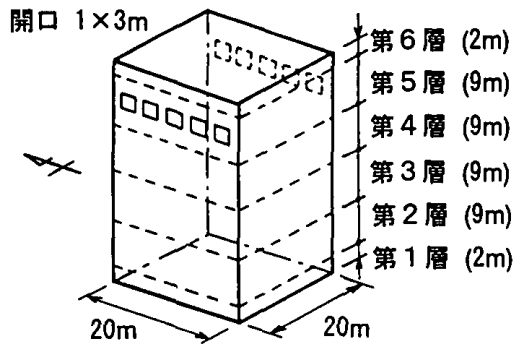

図12検証計算の対象としたアトリウム構造

表 2 想定したアトリウムの構造概要

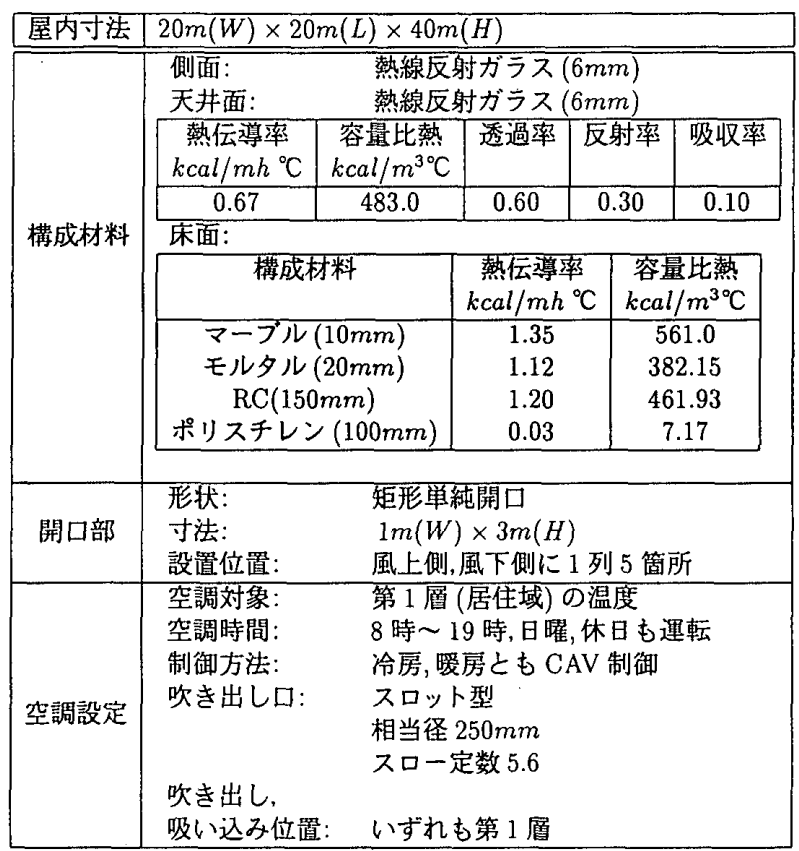

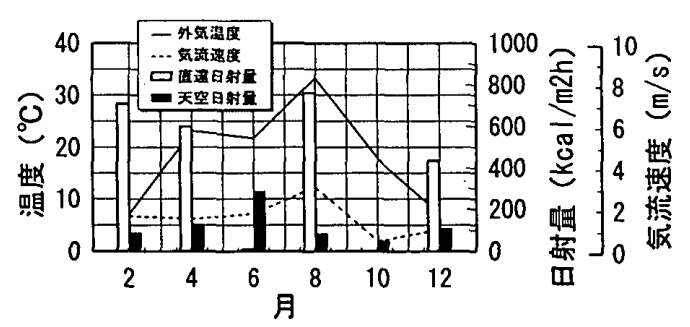

図 13 計算に用いた気象条件

層付近に空調吹き出し噴流と流入気流との干涉が認められ るが，干渉後の流入気流は緩やかに下降しながら本来の噴 流軌跡を保存しており，噴流間の干渉を考虑しない予测モ デルの結果ともよく整合している。これは開口からの流入 気流が有する慣性力によるものと考えられ，噴流間での干 渉を含むような場合でも開発した予测モデルによる現象予 測はある程度可能と考えられる。

4.2 各種条件での金直温度分布の比較

図 13 に示した気象条件を用いて各種条件でのアトリウ 厶内垂直温度分布を試計算した。図 15 は開口を設けた場 合, 開口なしの場合について, 隔月ごとの垂直温度分布の 変化を予測した結果である。開口を設けて外気を導入した 


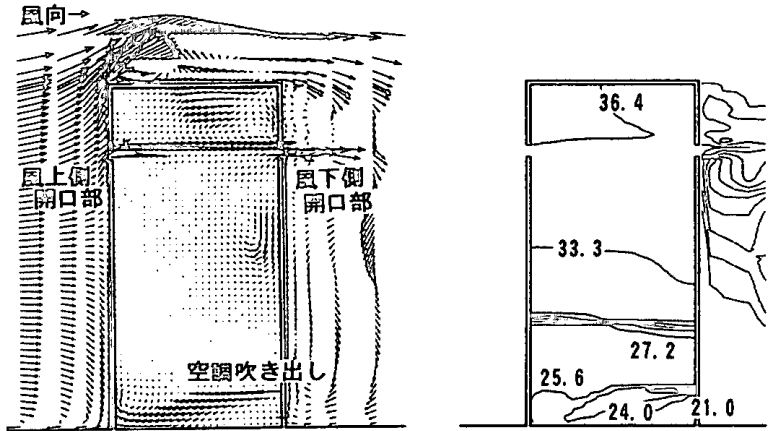

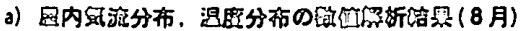

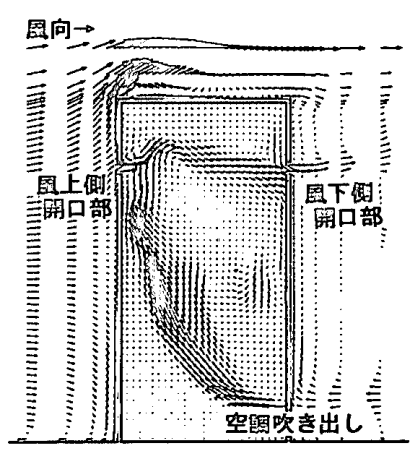

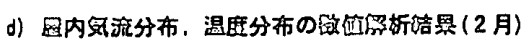

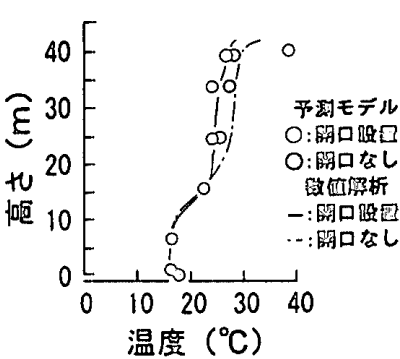

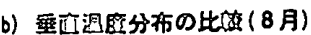

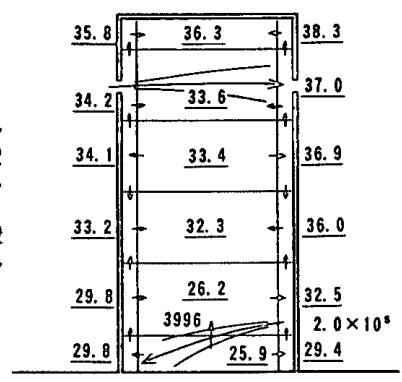

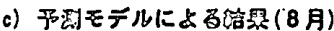

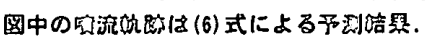

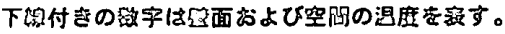

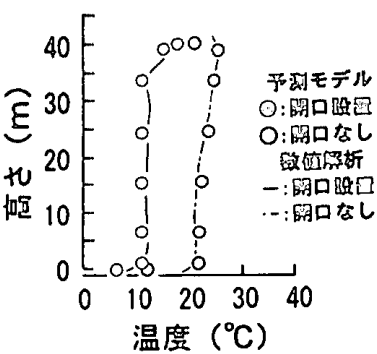

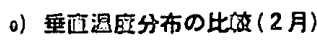

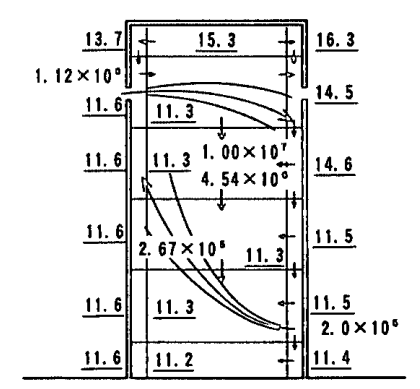

f) 予测そデルによる结黑 (2月)

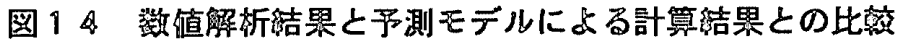

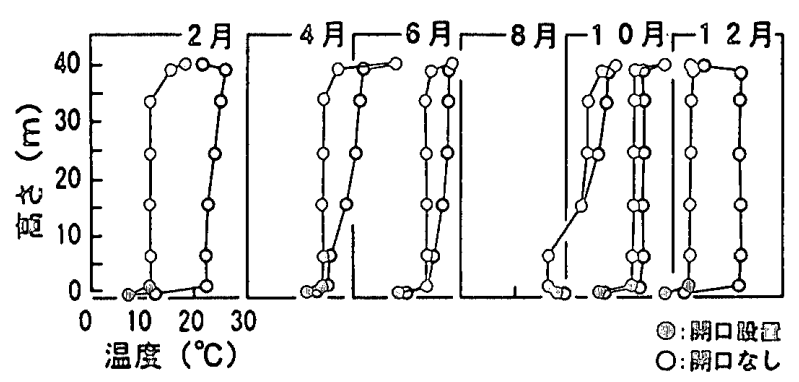

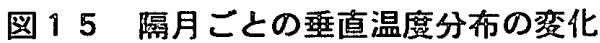

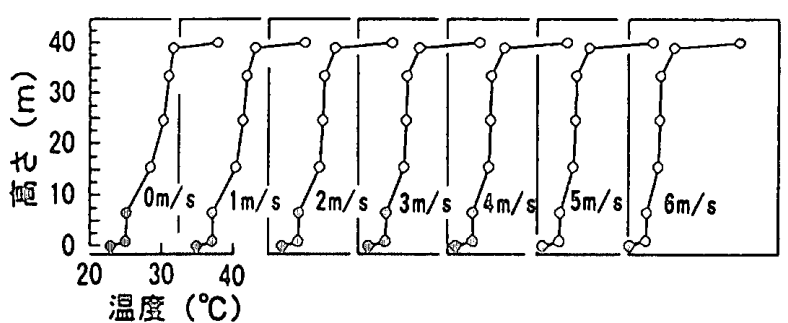

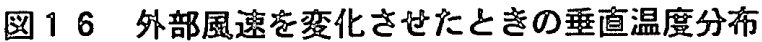

場合には屋内上部に形成される熱だまりが除去され，いず れの場合も上層部の温度が低下することがわかる。外気温 度が空調設定温度よりも低い 2 月，12月を除外すると，開 口部設置による熱だまりの除去効果を最も得られるのが中 間期の 4 月であることなど, 本モデルによる予測結果は経 験的な事実とも整合する。

中間期について外部気流速度を変化させた場合の垂直温 度分布の違いを比較した。各種風速条件について予測した 結果を図 16 に示す。屋内上部の温度は風速に対して単調 に低下しており，またこれに伴い変化する全体的な温度分
布の勾配も本予測モデルで再現可能なことがわかった。

4.3 各孚節における各層温度の日変化

季節ごとのアトリウム内各層温度の日変化を試計算し た。計算対象日の気象条件と合わせ，各季節についての予 測結果をまとめて図 17 に示す。4.1,4.2 節でも考察したよ うに，いずれの季節とも開口部を設置した場合には屋内上 層部での温度の低下が認められる。図に併記した天井表面 温度, 床表面温度の日変化は各層の温度変化と一致してお らず，ピークの現れる時刻が $2 \sim 3$ 時間のずれを生じてい る。これは日射量と外気温度の日変化のずれに起因するも のと考えられ，定性的には妥当な結果と考えられる。また 夏季の各層温度は 2 ヶ所のピークを示しており, 特に開口 を設けた場合にはその傾向がより顕著に現れている。本予 测モデルでは日射，熱貫流および外気の流入による効果を 考虑しており，ここで得られた結果はこれらの相互作用に よる結果と解釈できる。気象条件と比較すると，開口なし の条件における正午近傍での屋内温度の低下は天空日射量 の低下によるもの，開口を設置した場合の結果はさらにこ の前後での外気風速が大きくなることに起因するものと考 えられる。

\section{5. 結曹}

開口部から流入する自然換気流の特性を数值解析により 検討し，開口部を有するアトリウム空間に対応したマクロ

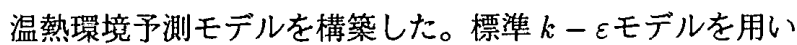
た数值解析の結果, 得られた知見は以下のとおりである。 1) 風上側壁面での風区係数の分布状態は風速や開口の有 

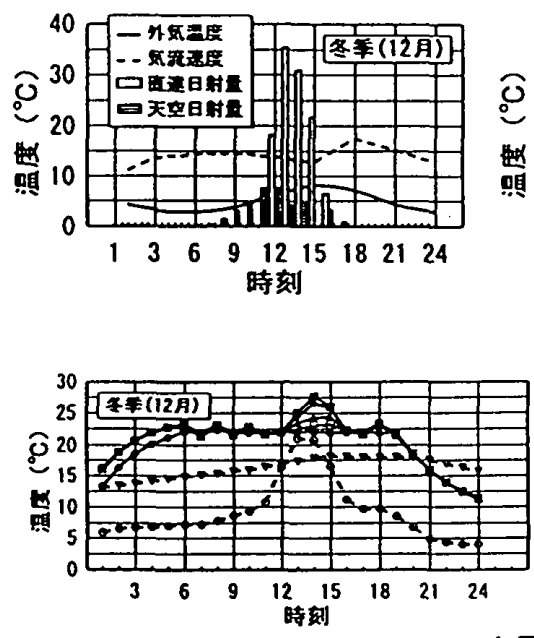

b) 各㴔
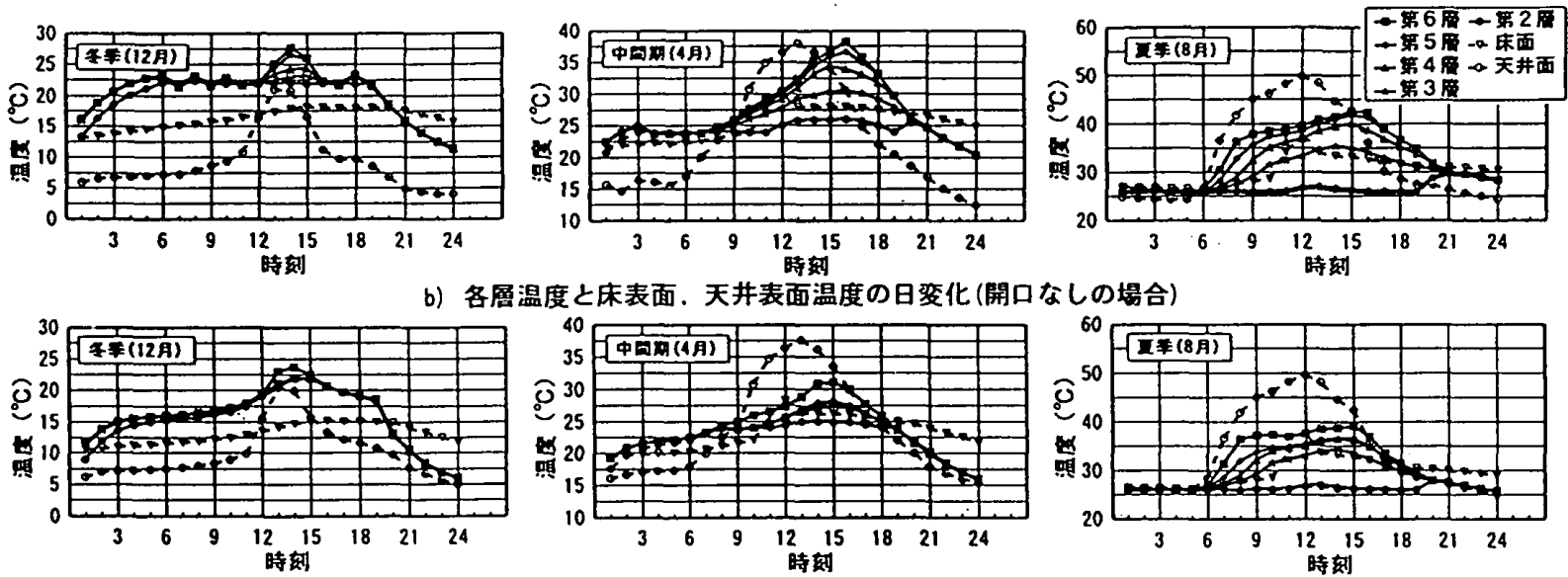

c）各層温度と床表面，天井表面温度の日要化(開口を設置した場合)

図 17 季節ことの各層温度の日変化の比較

無に影響されない。このため，開口のない場合につい て求めた風圧係数分布を用いて任意の開口条件に関す る通風量予测を行うことが可能である。この方法で予 测した通風量は，数值解析により求めたものと定量的 に一致した。

2) 開口からの流入気流の角度は，開口の設置高さにより 変化する。建築物高さに対する開口設置位置の比と流 入角度とは 2 次曲線で近似することが可能で，建築物 高さや風下側開口条件が異なる場合の特性も同一の近 似曲線で評価することが可能である。

3) 建築物の内部空間に対して開口面積が十分小さい場合, 屋內に流入した後の流入気流は噴流的なふるまいを示 す。解析結果から算出した主流域でのスロー定数の平 均值は，長方形吹きだしロからの噴流の值とほぼ同等 の値を示した。

考察結果をもとに開口からの流入気流の特性をマクロモデ ルに加え，開口を有する場合の屋内温熱環境予測モデルを 構築した。また本モデルを用いた試行計算を行い，以下の 結果を得た。

4) 夏期および冬季晴天日について本モデルによる屋内温 度分布，気流分布の予測を行い，数值解析による予測 と比較した結果，両者はよい一致を示した。

5) 夏季, 冬季および中間期について開口を設けた場合, 開口なしの場合の屋内垂直温度分布や屋内温度の日変 化を試計算した。その結果，中間期には開口の設置に より熱だまりの除去効果が期待できること，風速の違 いにより屋内温度分布が変化することなど，本予测モ
デにより定性的に妥当な特性を再現し得ることを確 認した。

以上の結果から，本予測モデルを用いて開口を有するアト リウム空間の温熱特性を十分な精度で予測できることを確 認した。今後, 開口条件をさまざまに変化させた場合や， 季節ごとの屋内温熱環境特性の違いなどについて検討を進 める予定である。

㙵 号

A： 太陽方位角 $\left({ }^{\circ}\right)$

$A_{i} \quad$ : 開口 $i$ の開口面積 $\left(\mathrm{m}^{2}\right)$,

$A_{f} \quad$ : 床面樻 $\left(\mathrm{m}^{2}\right)$,

$A r \quad:$ アルキメテス数,

$A w_{n} \quad: \quad n$ 壁の面積 $\left(m^{2}\right)$,

$C$ : 風圧係数,

$\mathrm{Cb}_{j i} \quad$ ： $i j$ 層間の乱流熱移動に関する係数 $\left(\mathrm{kcal} / \mathrm{hm}^{2}{ }^{\circ} \mathrm{C}\right)$,

$C p r$ ： 空気の容積比熱 $\left(k c a l / k g{ }^{\circ} \mathrm{C}\right)$,

$C_{s} \quad:$ 展開係数 $\left[=1 /\left(2 K_{p}\right)\right]$,

$D_{0} \quad$ : 開口の相当直径 $(m)$,

$g$ : 重力加速度 $\left(\mathrm{m} / \mathrm{s}^{2}\right)$,

$h \quad$ ：太陽高度 $\left(^{\circ}\right)$,

$H_{j} \quad$ : j層の内部発熱, $(k \mathrm{cal} / \mathrm{h})$

$H_{J E T}^{A C}$ ： 空調噴流により供給される熱量 $(\mathrm{kcal} / \mathrm{h})$,

$H_{J E T}^{N}$ ： 開口からの外気流入により供給される熱量 $(k c a l / h)$,

$K g$ ： ガラスの熱貫流率 $\left(\mathrm{kcal} / \mathrm{m}^{2} h^{\circ} \mathrm{C}\right)$

$K_{p} \quad$ : スロー定数,

$M_{j} \quad$ ： j層の空間熱容量 $\left(k c a l /{ }^{\circ} \mathrm{C}\right)$,

$N \quad$ : 開口の総数,

Nb ： 壁面の総数

$N k \quad$ ：層の分割数,

$p \quad$ : 軌道定数,

$P_{w} \quad$ : 風压力 $\left(\mathrm{kg} / \mathrm{m}^{2}\right)$, 


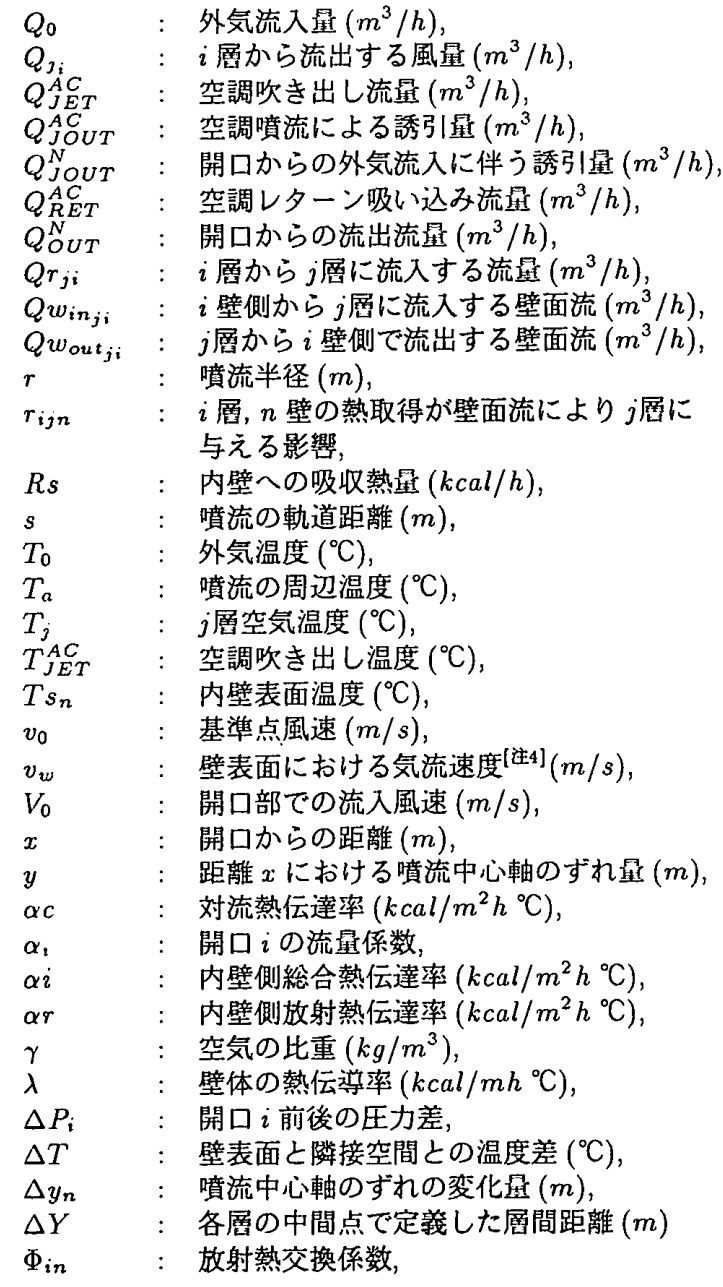

注

[注 1] 従来のマクロモデルでも, 外気の流入はすきま風的な扱い として考感されている。本研究では，外部気流によって駆動さ れる流入気流を開口により積極的に屋内に導入する場合を想定 しており，対象とする外気流入の形態，すなわちその物理的特 性は従来対象とされてきたものと異なる。

[注 2] 流入気流の直進性は, 風上側壁面積に対する相対的な開口 面積が小さいことに起因する较り効果的なものと考えられる。 本解析では建筮物高さを基準としてレイノルズ数 $10^{4}$ 想定し ているか，開口部での局所的なレイノルズ数は $10^{3}$ 程度あり,
流入気流は十分大きな慣性力を有する。

[注 3] ここで対象としている開口は矩形であり，厳密な意味では 軸対象噴流との比較は妥当ではない。しかし空間に対する吹き 出し口スケールが小さいことから，十分後流摡での特性は軸対 象噴流に近いものと考えた。

[注 4] 壁表面での熱伝達率は壁表面温度と温度境界層外側温度と の差によって定義されており，ここで用いる風速 $v_{w} に は$ 温度 境界層外側の值を適用する必要がある。本研究では対数則によ る壁関数を用いており，壁表面における風速プロファイルの立 ち上がりは急峻であると考えられる。このため壁面に隣接する 定哦点での值を近似的に用いて熱伝達率を求めた。本研究では スタガード格子系を用いているので，壁面から隣接定䉝点まで の距離は格子幅の $1 / 2$ となる。

\section{参考文献}

1) 日本建築学会編：アトリウムの環境設計 (1994), 彰国社.

2) 宮川：変分原理を用いた大空間の上下温度分布の計算法 (第 1 報)，空気調和衛生工学会論文集, 13(19906), 1.

3) 宮川：変分原理を用いた大空間の上下温度分布の計算法 (第 2 報)，空気調和衛生工学会論文集，13(19906)，13.

4) 戸河里，荒井，三浦：大空間の空謂・熱環境計画手法の研究 （その 1)，日本建築学会計画系論文報告集，427(19919)，9.

5) 戸河里, 荒井, 三浦 : 大空間の空調・熱環境計画手法の研究 (その 2)，日本建築学会計画系論文報告集，435(T9929), 11.

6) 石田，宇田川：上下温度分布を考虑した熱負荷計算 (その 1), 空気調和衙生工学会学術講演論文集, (1992 10j), 77.

7) 石田，宇田川：上下温度分布を考思した熱負荷計算 (その2), 空気調和衛生工学会学術講演論文集, (1992 10), 81.

8) Patankar, S.V. : Numerical Heat Transfer and Fluid Flow, Hemisphere Publishing Corp. (1980).

9) Leonard, B.P. : A Stable and Accurate Convective Modeling Procedure Based on Quadratic Up-stream Interpolation, Comput. Methods Appl. Mech. Eng., 19 (1979), 59.

10) Launder, B.E. and Spalding, D.B. : Mathematical Models of Turbulence, Academic Press (1972).

11) Schlichting, H. : Boundary-Layer Theory (1979 7th. ed.), MacGraw Hill, 729.

12) 井上: 空気調和ハンドブック (1991, 第 3 版)，丸普, 349 .

13) 戸河里, 荒井, 三浦 : 大空間の上下温度分布予測のための非 定常計算モデル(その2), 日本建筑学会計画系諭文報告集, 435(1992 5), 11.

14）絵内, 荒谷, 久保田, 松村 : 温度積層空間を上中下の 3 仮想室 に分割した非定常解析手法と大規模吹抜け空間への適用結果, 日本建築学会計画系論文報告集, 419(1991 1), 21. 